\title{
SYNTHESIS AND ANTITUBERCULAR ACTIVITY OF ISONIAZID CONDENSED WITH CARBOHYDRATE DERIVATIVES
}

Sílvia H. Cardoso, João Vítor de Assis e Mauro V. de Almeida*

Departamento de Química, Instituto de Ciências Exatas, Universidade Federal de Juiz de Fora, Cidade Universitária,

36036-330 Juiz de Fora - MG, Brasil

Maria Cristina S. Lourenço, Felipe R. C. Vicente e Marcus V. N. de Souza

Far Manguinhos, Fundação Oswaldo Cruz, 21041-250 Rio de Janeiro - RJ, Brasil

Recebido em 23/9/08; aceito em 21/1/09; publicado na web em 14/7/09

\begin{abstract}
A series of 13 compounds analogous of isoniazid condensed with carbohydrate was synthesized and evaluated for their in vitro antibacterial activity against Mycobacterium tuberculosis $H_{37} R v$ using Alamar Blue susceptibility test and the activity expressed as the minimum inhibitory concentration $\left(\mathrm{MIC}_{90}\right)$ in $\mu \mathrm{g} / \mathrm{mL}$. Several compounds exhibited antitubercular activity $(0.31-3.12 \mu \mathrm{g} / \mathrm{mL})$ when compared with first line drugs such as isoniazid (INH) and rifampicin (RIP) and could be a good starting point to develop new compounds against tuberculosis.
\end{abstract}

Keywords: isoniazid analogs; carbohydrate; antimycobacterial activity.

\section{INTRODUCTION}

Tuberculosis (TB), as declared by the World Health Organization (WHO) in 1993 has become a global health problem. This infectious disease is transmitted through the air by a Gram-positive bacterium Mycobacterium tuberculosis, which was first identified in 1882 by the German scientist Robert Koch (1843-1910). ${ }^{1,2}$ TB mainly affects the lungs (pulmonary TB), but in over $15 \%$ of patients this bacterium could infect different parts of the body, such as the brain, stomach, bones, skin, intestine, liver, kidneys, spinal cord and breasts. In general, TB disease in these parts of the body occurs more frequently in children and in people with a weak immune system, such as people infected by the Human Immunodeficiency Virus (HIV). Normally, the symptoms of pulmonary TB are chronic cough (for more than two weeks), coughing up of blood, weight loss, fever, pain in the chest, fatigue and sweating at night. ${ }^{3-5}$ Nowadays, according to statistics, TB kills four people every minute somewhere in the world and accounts about two million deaths per year. It is estimated that one-third of the world's population is currently infected with the TB bacillus and 30 million people will die in the next 10 years. ${ }^{6}$

At present, the treatment against TB involves three or four different kinds of antibacterial drugs given in combination over six to nine months. These are isoniazid (INH), pyrazinamide (PZA), ethambutol (EMB) and rifampicin (RIP) (Figure 1). ${ }^{7}$ Multiple combinations are necessary to prevent the emergence of multidrug resistant strains (MDR), which would lead to treatment failure.

Isonicotinic acid hydrazide or isoniazid (INH, see Figure 1) is one the more powerful synthetic agent against the $M$. tuberculosis complex and its minimum inhibitory concentration (MIC) is very low $(0.1-0.7 \mu \mathrm{M}){ }^{8}$ In the search of new compounds, isoniazid derivatives have been found to possess potential antitubercular activities. ${ }^{9}{ }^{10}$ Studies suggest that isoniazid, a prodrug which is converted into its active form by mycobacterial catalase-peroxidase, acts on the mycobacterial cell wall by preventing the FAS-II (fatty acid synthetase II) system from producing long chain fatty acid precursors for mycolic acid synthesis. ${ }^{11-14}$ Ventura and Martins ${ }^{14}$ postulated that the activation of isoniazid derivatives' prodrugs occurs near the surface of M. tuberculosis.

*e-mail: mauro.almeida@ufjf.edu.br

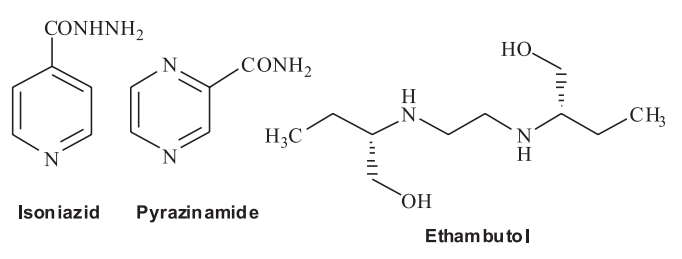

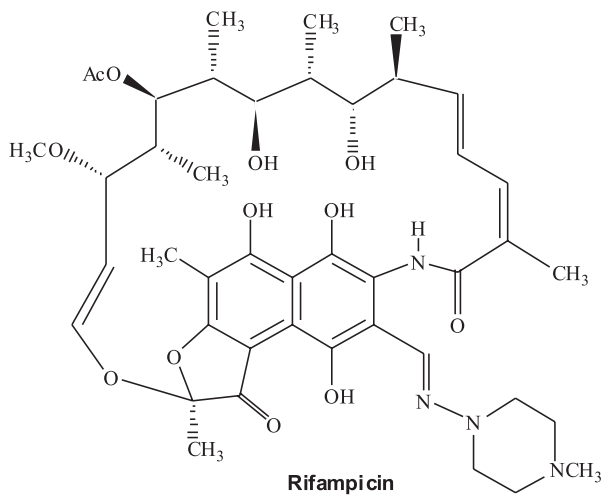

Figure 1. Essential antitubercular antibiotics

In this context, due to the growth of MDR-TB and extensively drug-resistant tuberculosis XDR-TB, which are strains resistant to first and second line anti-TB drugs, we urgently need new drugs and strategies to fight efficiently against this disease.

Fox ${ }^{15}$ described the preparation of some aldohexose, aldopentose, and fructosyl derivatives of isoniazid. This author claimed that these compounds are very active and relatively atoxic in mouse tuberculosis, although no biological data are furnished. Bernstein and co-workers ${ }^{16}$ reported the synthesis of isonicotinyl hydrazones from L-arabinose, D-glucose, and D-galactose and others sugars not described in the present article. Little information about structural elucidation, conformation and biological activity was reported in these papers.

Considering the fundamental presence of carbohydrate, such as peptidoglycan and arabinogalactan, in the construction of the mycobacterial cell walls ${ }^{17-19}$ and the reaction between INH and aldehydes (e.g. glucose and lactose) in drug formulations, ${ }^{20}$ in this work we 


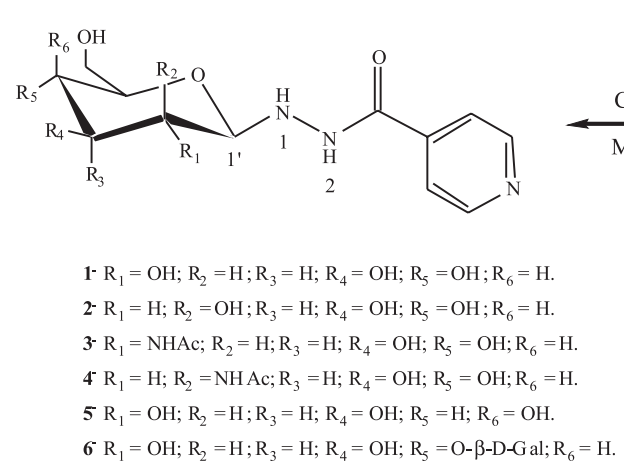

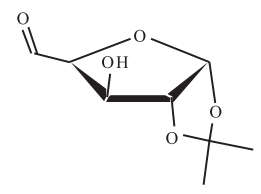

14

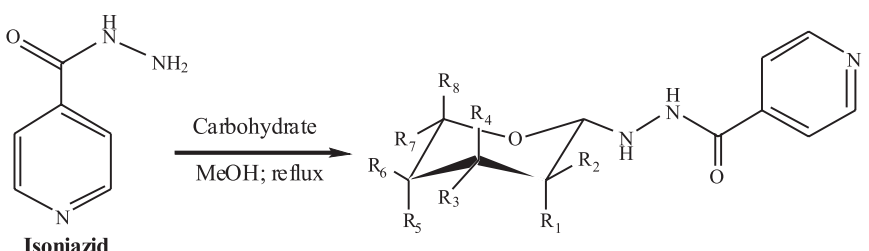

$$
\begin{aligned}
& \text { 8a- } \mathrm{R}_{1}=\mathrm{H} ; \mathrm{R}_{2}=\mathrm{OH} ; \mathrm{R}_{3}=\mathrm{OH} ; \mathrm{R}_{4}=\mathrm{H} ; \mathrm{R}_{5}=\mathrm{OH} ; \mathrm{R}_{6}=\mathrm{H} ; \mathrm{R}_{7}=\mathrm{R}_{8}=\mathrm{H} \text { and } \\
& \mathbf{8 b} \text { ac yclic form } \\
& \text { 9- } \mathrm{R}_{1}=\mathrm{OH} ; \mathrm{R}_{2}=\mathrm{H} ; \mathrm{R}_{3}=\mathrm{OH} ; \mathrm{R}_{4}=\mathrm{H} ; \mathrm{R}_{5}=\mathrm{H} ; \mathrm{R}_{6}=\mathrm{OH} ; \mathrm{R}_{7}=\mathrm{CH}_{3} ; \mathrm{R}_{8}=\mathrm{H} \\
& 10-\mathrm{R}_{1}=\mathrm{H} ; \mathrm{R}_{2}=\mathrm{OH} ; \mathrm{R}_{3}=\mathrm{OH} ; \mathrm{R}_{4}=\mathrm{H} ; \mathrm{R}_{5}=\mathrm{OH} ; \mathrm{R}_{6}=\mathrm{H} ; \mathrm{R}_{7}=\mathrm{CH}_{3} ; \mathrm{R}_{8}=\mathrm{H} \\
& \text { 11a- } \mathrm{R}_{1}=\mathrm{OH} ; \mathrm{R}_{2}=\mathrm{H} ; \mathrm{R}_{3}=H ; \mathrm{R}_{4}=\mathrm{OH} ; \mathrm{R}_{5}=H ; \mathrm{R}_{6}=\mathrm{OH} \text { and } 11 \mathrm{~b} \text { a cyclic form } \\
& \text { 12a- } \mathrm{R}_{1}=\mathrm{H} ; \mathrm{R}_{2}=\mathrm{OH} ; \mathrm{R}_{3}=\mathrm{H} ; \mathrm{R}_{4}=\mathrm{OH} ; \mathrm{R}_{5}=\mathrm{H} ; \mathrm{R}_{6}=\mathrm{OH} \text { and } \mathbf{1 2} \mathbf{b} \text { a cyclic } \\
& \text { form } \\
& 13-\mathrm{R}_{1}=\mathrm{H} ; \mathrm{R}_{2}=\mathrm{OH} ; \mathrm{R}_{3}=\mathrm{OH} ; \mathrm{R}_{4}=\mathrm{H} ; \mathrm{R}_{5}=\mathrm{H} ; \mathrm{R}_{6}=\mathrm{OH} ; \mathrm{R}_{7}=\mathrm{R}_{8}=\mathrm{H}
\end{aligned}
$$
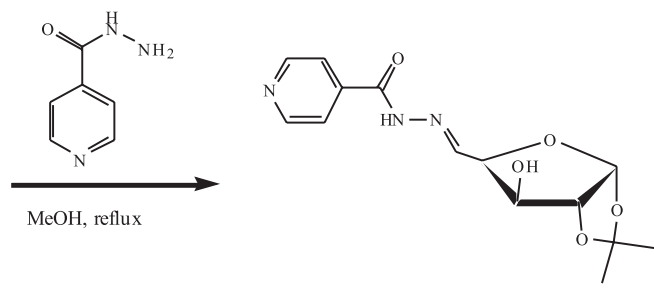

$7(20 \%$ in 4 steps $)$

Scheme 1. Preparation of isoniazid derivatives

report the synthesis (Scheme 1) and preliminary in vitro antitubercular activity of a series of 13 derivatives of isoniazid condensed with carbohydrate.

\section{RESULTS AND DISCUSSION}

The preparation of the compounds described in this work involved the reaction between isoniazid and appropriate carbohydrates in methanol at reflux, leading to the desired compounds 1-13 in 20-75\% yields (Scheme 1). Aldehyde 14 was prepared from $\mathrm{D}$-glucose in three steps and treated with isoniazid to furnish the corresponding hydrazone 7 (Scheme 1). All the compounds were identified by spectral data and although one major peak was usually observed, there were 1-3 additional peaks for each compound. The molecules were found to exist primarily as cyclic products. The conformations were assigned based on $J$ couplings of ring protons and the relatively upfield chemical shifts of H-1 for the cyclic compounds. In the hexose series it was observed that the 2-isonicotinoylhydrazine function favors an equatorial orientation and the pyranose rings forms were dominant. ${ }^{21}$ For example, with the D-glucose $\mathbf{1}$ and D-galactose 5 derivatives only the $\beta$-pyranosyl form $\left({ }^{4} \mathrm{C}_{1}\right.$ conformation $)$ was observed. ${ }^{11,12}$ The 2-isonicotinoylhydrazine function was also equatorially disposed in the L-fucosyl and L-rhamnosyl products which, by nomenclature convention, ${ }^{22}$ were the ${ }^{1} \mathrm{C}_{4}$ conformer. For the L-series derivatives the pyranosyl form $\left({ }^{1} \mathrm{C}_{4}\right.$ conformation) was found as the major product. In the pentose series, the products from D or L-arabinose, 8 and 11 respectively, and Lribose $\mathbf{1 2}$ were obtained as a mixture of cyclic and open-chain form products.

In general, IR spectra showed the $\mathrm{OH}$ peaks at $3460-3370$ $\mathrm{cm}^{-1}$ and $\mathrm{C}=\mathrm{O}$ and/or $\mathrm{C}=\mathrm{N}$ peaks at $1669-1621 \mathrm{~cm}^{-1}$. The ${ }^{1} \mathrm{H}$ NMR spectrum showed the corresponding signals to the anomeric protons $\mathrm{H}-1$ ' between $\delta$ 4.63-4.00. Coupling constant values from $J_{1-2}$ were consistent with the D,L-pyranosyl form $\left({ }^{4} \mathrm{C}_{1}\right.$ or ${ }^{1} \mathrm{C}_{4}$ conformation). Signals for the aromatics protons were observed at $\delta 8.65$ and $\delta$ 7.65. The ${ }^{13} \mathrm{C}$ NMR spectrum showed the signals corresponding to amide $\mathrm{C}=\mathrm{O}$ at $\delta$ 170.9-167.2. All spectra presented a new signal attributed to anomeric carbon C-1'. Signal corresponding to the carbohydrates moiety were observed between $\delta$ 79.3-52.1, while the aromatic carbons C-3 and C-5 at $\delta 122.0, \mathrm{C}-4$ at $\delta 140.5$ and C-2 and C-6 were observed at $\delta$ 150.0. In the compounds $\mathbf{8 , 1 1}$ and 12 the carbon corresponding to the open-chain form $(\mathrm{HC}=\mathrm{N})$ was observed between $\delta$ 155.0-153.0.

\section{Biological evaluation}

The antimycobacterial activities of compounds 1-13 were assessed against $M$. tuberculosis ATTC $2729^{23}$ using the micro plate Alamar Blue assay (MABA) ${ }^{24}$ (Table 1). This methodology is nontoxic, uses thermally-stable reagents and shows good correlation with proportional and BACTEC radiometric methods. ${ }^{25,26}$ Briefly, two hundred microliters of sterile deionized water was added to all outer-perimeter wells of sterile 96 well plates (Falcon, 3072: Becton Dickinson, Lincoln Park NJ) to minimize evaporation of the medium in the test wells during incubation. The 96 plates received $100 \mu \mathrm{L}$ of the Middlebrook $7 \mathrm{H} 9$ broth (Difco Laboratories, Detroit, MI, USA) and a serial dilution of the compounds was made directly on the plate. The final drug concentrations tested were 0.01 to $10.0 \mu \mathrm{L} / \mathrm{mL}$. Plates were covered and sealed with parafilm and incubated at $37{ }^{\circ} \mathrm{C}$ for five days. After this time, $25 \mu \mathrm{L}$ of a freshly prepared 1:1 mixture of Alamar Blue (Accumed International, Westlake Ohio) reagent and $10 \%$ Tween 80 were added to the plate and incubated for twenty-four hours. A blue color in the well was interpreted as absence of bacterial growth and a pink color was scored as growth. The MIC (Minimal Inhibition Concentration) was defined as the lowest drug concentration to give $90 \%$ inhibition of bacterial growth, which prevented a color change from blue to pink.

The results show that some compounds exhibited activity against M. tuberculosis. The best results were obtained with the mixture of compounds 11a and 11b, in equilibrium, that exhibited a $\mathrm{MIC}_{90}$ of $0.31 \mu \mathrm{g} / \mathrm{mL}$ (Table 1). Compounds 1, 2, 5, 6, 7, 9, 10 and 13 exhibited activity between 0.62 and $3.12 \mu \mathrm{g} / \mathrm{mL}$ when compared with first line drugs such as isoniazid (INH) and rifampin (RIP). 
Table 1. The in vitro activity of compounds 1-13 against $M$. tuberculosis $\mathrm{H}_{37} \mathrm{Rv}$ strain (ATCC 27294, susceptible both to rifampicin and isoniazid)

\begin{tabular}{lccc}
\hline Compound & Carbohydrate & Yield $(\%)$ & $\begin{array}{c}\mathrm{MIC}_{90} \\
(\mu \mathrm{g} / \mathrm{mL})\end{array}$ \\
\hline $\mathbf{1}$ & D-Glucose & 73 & 1.25 \\
$\mathbf{2}$ & D-Mannose & 65 & 3.12 \\
$\mathbf{3}$ & $N$-Acetyl-D-glucosamine & 30 & $>100$ \\
$\mathbf{4}$ & $N$-Acetyl-D-mannosamine & 22 & $>100$ \\
$\mathbf{5}$ & D-Galactose & 75 & 0.62 \\
$\mathbf{6}$ & D-Lactose & 63 & 2.5 \\
$\mathbf{7}$ & D-Ribose & 20 & 0.62 \\
$\mathbf{8 a}+\mathbf{8 b}$ & D-Arabinose & 67 & $>100$ \\
$\mathbf{9}$ & L-Rammose & 51 & 0.62 \\
$\mathbf{1 0}$ & L-Fucose & 50 & 0.62 \\
$\mathbf{1 1 a}+\mathbf{1 1 b}$ & L-Arabinose & 36 & 0.31 \\
$\mathbf{1 2 a}+\mathbf{1 2 b}$ & L-Ribose & 50 & $>100$ \\
$\mathbf{1 3}$ & L-Xylose & 63 & 3.12 \\
$\mathrm{INH}$ & Isoniazid & - & 0.2 \\
$\mathrm{RIP}$ & Rifampicin & - & 1.0 \\
\hline
\end{tabular}

\section{CONCLUSION}

In conclusion, the preliminary antimycobacterial activities study of 13 compounds based on the coupling of isoniazid with different carbohydrates described here suggest that they may be selectively targeted to M. tuberculosis growth. The compounds exhibited activity against $M$. tuberculosis $\mathrm{H}_{37} \mathrm{Rv}$ (ATTC 27294) in the range 0.31-3.12 $\mu \mathrm{g} / \mathrm{mL}$ when compared with first line drugs such as isoniazid (INH) and rifampicin (RIP), and could be a good starting point for further studies as well as find new lead compounds.

\section{EXPERIMENTAL}

\section{General procedures}

Melting points were determined on a Tomas-Hoover apparatus and are uncorrected. Infrared spectra were recorded on a BomemFTIR MB-102 spectrometer and frequencies are expressed in $\mathrm{cm}^{-1}$. Mass spectra were obtained with a Maldi-Tof instrument for high resolution mass spectra (HREIMS). NMR spectra were recorded on a Bruker Avance spectrometer operating at $300.00 \mathrm{MHz}\left({ }^{1} \mathrm{H}\right)$ and $75.0 \mathrm{MHz}\left({ }^{13} \mathrm{C}\right)$, in deuterated water. Chemical shifts are reported in $\mathrm{ppm}(\delta)$ relative to tetramethylsilane. Proton and carbon spectra were typically obtained at room temperature. The aldehyde $\mathbf{1 4}$ was prepared in three steps from D-glucose. ${ }^{27,28}$

\section{General procedure for the preparation of derivatives 1-13}

To a solution of the isoniazid ( $4.2 \mathrm{mmol}, 1.5$ equiv.) in methanol $(20 \mathrm{~mL})$ at $60{ }^{\circ} \mathrm{C}$ was added $(2.8 \mathrm{mmol})$ of the carbohydrate. The reaction mixture was stirred at this temperature for $24 \mathrm{~h}$ and the solid formed was filtered and washed with warmed methanol. The solid obtained was recrystallized in a mixture of methanol/water to furnish compounds 1, 5, 6, 8, 9, 10 and 11. For compounds 2, 3, 4, 12 and 13 the purification was realized by chromatography using as eluent a gradient of ethyl acetate and methanol.
1-(1'- $\beta$-D-Glucopyranosyl)-2-isonicotinoyl-hydrazine 1

Yield 73\%; m.p. (162-163 ${ }^{\circ} \mathrm{C}$, Lit. ${ }^{15} 160^{\circ} \mathrm{C}$ ); IR (KBr) 3483, 2929, 2884, 1664, 1548, 1100 and $1024 \mathrm{~cm}^{-1}$; ${ }^{1} \mathrm{H}$ NMR (300 MHz, D O) 8 3.29-3.42 (m, 3H, H-5', H-2', H-4'), 3.53 (dd, 1H, H-3', J 8.7, J 9.7Hz), 3.67 (dd, 1H, H-6'b, J 5.6, J 12.8Hz), 3.85 (dd, 1H, H-6'a, $J 12.8 \mathrm{~Hz}), 4.17$ (d, 1H, H-1', J 8.9Hz), 7.63 (d, 2H, H-3, H-5, $J$ $6.2 \mathrm{~Hz}), 8.61$ (d, 2H, H-2, H-6, J 5.3Hz); ${ }^{13} \mathrm{C} \mathrm{NMR}\left(300 \mathrm{MHz}, \mathrm{D}_{2} \mathrm{O}\right)$ 反 62.8 (C-6'), 71.5 (C-4'), 72.7 (C-2'), 78.2 (C-5'), 78.8 (C-3'), 91.7 (C-1'), 123.7 (C-3, C-5), 142.6 (C-4), 152.4 (C-2, C-6), 169.9 $(\mathrm{C}=\mathrm{O})$; HREIMS $\mathrm{m} / z$, calcd. for $\mathrm{C}_{12} \mathrm{H}_{17} \mathrm{~N}_{3} \mathrm{NaO}_{6}[\mathrm{M}+\mathrm{Na}]^{+}: 322.1010$, found 322.1021 .

1-(1'-ß-D-Mannopyranosyl)-2-isonicotinoyl-hydrazine 2

Yield 65\%; (oil); IR (KRS-5) 3480, 2930, 2884, 1664, 1548 and $1100 \mathrm{~cm}^{-1}$; ${ }^{1} \mathrm{H}$ NMR (300 MHz, D O): 3.57 (t, 1H, H-4', $J$ 9.3Hz); 3.66-3.75 (m, 2H, H-3', H-6'b); 3.83-3.89 (m, 1H, H-5'); 3.93-3.96 (m, 1H, H-6'a); 4.14 (dd, 1H, H-2', J 3.4, J $1.0 \mathrm{~Hz}$ ); 4.41 (d, 1H, H-1', $J \leq 1.0 \mathrm{~Hz}$ ); 7.65-7.69 (m, 2H, H-3, H-5); 8.65-8.67 (m, 2H, H-2, H-6); ${ }^{13} \mathrm{C}$ NMR (300 MHz, D 2 ): 61.4 (C-6'), 67.3 (C-4'), 69.9 (C-2'), 73.6 (C-3'), 77.4 (C-5'), 87.6 (C-1'), 122.0 (C-3, C-5), 141.0 (C-4), $149.6(\mathrm{C}-2, \mathrm{C}-6), 167.9(\mathrm{C}=\mathrm{O})$.

1-(1'- $\beta-D-2$ '-Acetamido-2'-deoxy-glucopyranosyl)-2-isonicotinoylhydrazine 3

Yield 30\%; (oil); IR (CsI) 3463, 3322, 3077, 2922, 1628, 1554 and $1048 \mathrm{~cm}^{-1}$; ${ }^{1} \mathrm{H}$ NMR $\left(300 \mathrm{MHz}, \mathrm{D}_{2} \mathrm{O}\right) \delta 2.03\left(\mathrm{~s}, 3 \mathrm{H}, \mathrm{CH}_{3}\right), 3.32(\mathrm{~s}$, 1H, NH), 3.42-3.44 (m, 2H, H-4', H-6'a), 3.56-3.65 (m, 1H, H-5'), 3.73 (dd, 1H, H-6'b J 4.4, J 11.0Hz), 3.86-3.93 (m, 2H, H-2', H-3'), 4.33 (d, 1H, H-1', J 9.6Hz), 7.65 (d, 2H, H-3, H-5 J 4.6Hz), 8.64 (d, $2 \mathrm{H}, \mathrm{H}-2, \mathrm{H}-6, J 4.6 \mathrm{~Hz}) ;{ }^{13} \mathrm{C} \mathrm{NMR}\left(300 \mathrm{MHz}, \mathrm{D}_{2} \mathrm{O}\right) \delta 22.2\left(\mathrm{CH}_{3}\right)$, 52.1 (C-2'), 60.7 (C-6'), 69.8 (C-4'), 74.7 (C-3'), 77.0 (C-5'), 88.3 (C-1'), 122.0 (C-3, C-5), 141.2 (C-4), 149.2, 149.3 (C-2, C-6), 167.3 $(\mathrm{C}=\mathrm{O}), 174.6(\mathrm{C}=\mathrm{O})$.

1-(1'- $\beta$-D-2'-Acetamido-2'-deoxy-mannopyranosyl)-2-isonicotinoylhydrazine 4 ( $\alpha$ and $\beta$ isomers)

Yield 22\%; (oil); IR (CsI) 3393, 2935, 1660, 1551 and $1067 \mathrm{~cm}^{-1} ;{ }^{1} \mathrm{H}$ NMR (300 MHz, D O) $\delta 2.03$ (s, 3H, CH ), 3.30-3.88 (m, 6H, H-2', H-3', H-4', H-5', H-6' a, H-6'b), 4.45 (d, 1H, H-1' J $\leq 1.0 \mathrm{~Hz}), 7.65-$ 7.69 (m, 3H, H-3, H-5), 8.64-8.67 (m, 3H, H-2, H-6); ${ }^{13} \mathrm{C}$ NMR (300 $\left.\mathrm{MHz}, \mathrm{D}_{2} \mathrm{O}\right) \delta 22.2\left(\mathrm{CH}_{3}\right), 52.2\left(\mathrm{C}-2^{\prime} \alpha\right), 52.3\left(\mathrm{C}-2^{\prime} \beta\right), 60.5\left(\mathrm{C}-6{ }^{\prime} \alpha\right)$, 60.9 (C-6' $\beta), 67.1$ (C-4' $\left.\alpha, \mathrm{C}^{\prime} 4^{\prime} \beta\right), 69.7$ (C-3' $\left.\alpha\right), 70.2$ (C-3' $\left.\beta\right), 72.7$ $\left(\mathrm{C}-5^{\prime} \beta\right), 73.2\left(\mathrm{C}-5^{\prime} \alpha\right)$; $80.3\left(\mathrm{C}-1^{\prime} \alpha\right), 87.3\left(\mathrm{C}-1^{\prime} \beta\right), 121.9-122.1(\mathrm{C}-3$, C-5), 140.9 (C-4), 149.6 (C-2, C-6), 168.0, 168.1 (C=O), 174.7, 175.7 $(\mathrm{C}=\mathrm{O})$. The product from $\mathrm{D}$-mannosamine is a mixture of $\alpha$ and $\beta$ isomers and the ${ }^{1} \mathrm{H}$ NMR data was deduced from major isomer $\beta$.

1-(1' $\beta$-D-Galactopyranosyl)-2-isonicotinoyl-hydrazine 5 Yield 63\%; m.p. (163-166 ${ }^{\circ} \mathrm{C}$, Lit. ${ }^{15} 156^{\circ} \mathrm{C}$ ); IR (KBr) 3420, 2936, 2856, 1658, 1104 and $1041 \mathrm{~cm}^{-1}$; ${ }^{1} \mathrm{H}$ NMR (300 MHz, D O) $\delta 3.54-$ 3.89 (m, 6H, H-2', H-3', H-4', H-5', H-6', H-6' '), 4.14 (d, 1H, H-1' $J$ 8.8Hz), 7.63 (d, 2H, H-3, H-5 J 5.5Hz), 8.59 (d, 2H, H-2, H-6, $J$ 5.5Hz); ${ }^{13} \mathrm{C}$ NMR (300 MHz, $\left.\mathrm{D}_{2} \mathrm{O}\right) \delta 61.5$ (C-6'), 68.5 (C-4'), 68.9 (C-3'), 73.4 (C-2'), 76.4 (C-5'), 91.7 (C-1'), 123.7 (C-3, C-5), 142.6 (C-4), 152.4 (C-2, C-6), $169.9(\mathrm{C}=\mathrm{O})$; HREIMS $\mathrm{m} / \mathrm{z}$ calcd. for $\mathrm{C}_{12} \mathrm{H}_{17} \mathrm{~N}_{3} \mathrm{NaO}_{6}[\mathrm{M}+\mathrm{Na}]^{+}:$322.1010, found 322.1023.

1-(1'ß-D-Lactosylpyranosyl)-2-isonicotinoyl-hydrazine 6 Yield 75\%; m.p. $\left(212-213{ }^{\circ} \mathrm{C}\right.$, Lit. ${ }^{15} 204{ }^{\circ} \mathrm{C}$ ); IR (KBr) 3528-3109, 2914, 2871, 1661 and $1029 \mathrm{~cm}^{-1}$; ${ }^{1} \mathrm{H}$ NMR (300 MHz, D O) $\delta 3.45-$ 4.03 (m, 12H, H-2', H-3', H-4', H-5', H-6'a, H-6'b, H-2', H-3', H-4', H-5", H-6"'a, H-6"'b), 4.32 (d, 1H, H-1' J 9.0Hz), 4.49 (d, 1H, 
H-1" J 7.4Hz), 7.75 (d, 2H, H-3, H-5 J 5.5Hz), 8.73 (d, 2H, H-2, H-6, J 5.5Hz); ${ }^{13} \mathrm{C}$ NMR (300 MHz, D O) $\delta 61.1$ (C-6'), 61.9 (C-6" ), 69.5 (C-4”), 71.5 (C-2'), 71.9 (C-2”), 73.5 (C-3”), 75.9 (C-5'), 76.3 (C5”), 76.8 (C-3'), 79.3 (C-4'), 92.4 (C-1'), 105.7 (C-1”), 124.6 (C-3, C-5), 143.5 (C-4), $152.4(\mathrm{C}-2, \mathrm{C}-6), 170.9(\mathrm{C}=\mathrm{O})$; HREIMS m/z calcd for $\mathrm{C}_{18} \mathrm{H}_{27} \mathrm{~N}_{3} \mathrm{NaO}_{11}[\mathrm{M}+\mathrm{Na}]^{+}:$484.1646, found 484.1535.

$\alpha$-D-Xylopentodialdo-1,4-furanose-1,2-O-isopropylideneisonicotinoyl-hydrazone 7 Yield 20\%, m.p. (157-160 ${ }^{\circ} \mathrm{C}$ ); IR (KBr) 3449, 3255, 2989, 2937, 1660, 1548, 1074 and $1016 \mathrm{~cm}^{-1}$; ${ }^{1} \mathrm{H}$ NMR (300 MHz, D $\left.\mathrm{O}\right) \delta 1.26\left(\mathrm{~s}, 3 \mathrm{H}, \mathrm{CH}_{3}\right), 1.58\left(\mathrm{~s}, 3 \mathrm{H}, \mathrm{CH}_{3}\right)$, 4.52-4.96 (m, 3H, H-2', H-3', H-4'), 6.17 (d, 1H, H-1'J 3.6Hz), 7.75-7.78 (m, 3H, H-3, H-5, H-5'), 8.72-8.75 (m, 2H, H-2, H-6); ${ }^{13} \mathrm{C}$ NMR $\left(300 \mathrm{MHz}, \mathrm{D}_{2} \mathrm{O}\right) \delta$ 25.5, $25.6\left(\mathrm{CH}_{3}\right), 75.6(\mathrm{C}-3$ '), 80.0 (C-2'), 84.6 (C-4'), 104.8 (C-1'), 113.1 (C isopr.), 122.0 (C-3, C-5), 140.2 (C-4), $149.6(\mathrm{C}-2, \mathrm{C}-6) ; 150.0(\mathrm{C}=\mathrm{N})$; C H N (\%): found $\mathrm{C} 41.61, \mathrm{H} 5.48, \mathrm{~N} 10.84 ; \mathrm{C}_{14} \mathrm{H}_{27} \mathrm{~N}_{3} \mathrm{O}_{10}$ requires $\mathrm{C} 42.31$, $\mathrm{H}$ 6.85, N 10.57; HREIMS $m / z$ calcd for $\mathrm{C}_{14} \mathrm{H}_{17} \mathrm{~N}_{3} \mathrm{O}_{5} \mathrm{Na}[\mathrm{M}+\mathrm{Na}]^{+}$: 330.1646 , found 330.1068 .

\section{1-(1'-D-arabinosyl)-2-isonicotinoyl-hydrazine $\mathbf{8 a}$ and $\mathbf{8 b}$}

Yield 67\%; IR (KBr) 3488, 3217, 3071, 2943, 1664, 1644, 1555, 1090 and $1043 \mathrm{~cm}^{-1}$; ${ }^{1} \mathrm{H}$ NMR (300 MHz, D O) $\delta 3.59-4.63(\mathrm{~m}, 6 \mathrm{H}$, H-1', H-2', H-3', H-4', H-5', H-5' ) 7.62-7.83 (m, 2H, H-3, H-5), 8.64-8.68 (m, 2H, H-2, H-6); ${ }^{13} \mathrm{C}$ NMR (300 MHz, D O) $\delta 61.3-77.9$ (C-2', C-3', C-4', C-5'), 82.4-94.2 (C-1'), 122.4, 122.7 (C-3, C-5), 140.4, 140.8 (C-4), 149.7 (C-2, C-6), $155.3(\mathrm{C}=\mathrm{N}$, acyclic form), 167.5-167.9 $(\mathrm{C}=\mathrm{O})$.

\section{1-(1'-3-L-Ramnopyranosyl)-2-isonicotinoyl-hydrazine 9}

Yield 51\%; m.p. (187-188 $\left.{ }^{\circ} \mathrm{C}\right)$; IR (KBr) 3480, 3240, 2915, 2862, 1634, 1552 and $1074 \mathrm{~cm}^{-1}$; ${ }^{1} \mathrm{H}$ NMR (300 MHz, D O) $\delta 1.26(\mathrm{~d}, 3 \mathrm{H}$, $\mathrm{CH}_{3} J 5.5 \mathrm{~Hz}$ ), 3.31-3.39 (m, 2H, H-4', H-5'), 3.56 (dd, 1H, H-3' $J$ $3.3, J 9.0 \mathrm{~Hz}), 4.08$ (d, 1H, H-2'J 3.3Hz), 4.36 (s, 1H, H-1') 7.66 (d, 2H, H-3, H-5 J 6.4Hz), 8.65 (d, 2H, H-2, H-6, J 6.4Hz); ${ }^{13} \mathrm{C}$ NMR (300 MHz, D O) $\delta 16.9\left(\mathrm{CH}_{3}\right), 69.9\left(\mathrm{C}^{\prime} 5^{\prime}\right), 72.3\left(\mathrm{C}-3^{\prime}\right), 73.3-73.4$ (C-2', C-4'), 87.4 (C-1'), 121.8, 121.9 (C-3, C-5), 140.8 (C-4), 149.6 (C-2, C-6), $167.4(\mathrm{C}=\mathrm{O})$; C H N (\%): found C 50.47, H 5.78, N 14.25; $\mathrm{C}_{12} \mathrm{H}_{17} \mathrm{~N}_{3} \mathrm{O}_{5}$ requires $\mathrm{C} 50.88, \mathrm{H} 6.05, \mathrm{~N} 14.83$.

1-(1'-3-L-Fucopyranosyl)-2-isonicotinoyl-hydrazine 10

Yield 50\%; m.p. (170-171 $\left.{ }^{\circ} \mathrm{C}\right)$; IR (KBr) 3419, 3285, 3089, 2998, 2888, 1621, 1550, 1078 and $1041 \mathrm{~cm}^{-1}$; ${ }^{1} \mathrm{H}$ NMR (300 MHz, D O) $\delta$ 1.23 (s, 3H, $\left.\mathrm{CH}_{3}\right), 3.54$ (dd, 1H, H-2'J 9.0, J 9.6Hz), 3.69 (dd, $1 \mathrm{H}$, H-3' J 3.3, J 9.6Hz), 3.76-3.81 (m, 2H, H-4', H-5'), 4.15 (d, 1H, H-1', $J 9.0 \mathrm{~Hz}$ ), 7.68 (d, 2H, H-3, H-5, J 6.5Hz), 8.65 (d, 2H, H-2, H-6, J $6.5 \mathrm{~Hz}) ;{ }^{13} \mathrm{C}$ NMR (300 MHz, $\left.\mathrm{D}_{2} \mathrm{O}\right) \delta 15.1\left(\mathrm{CH}_{3}\right), 67.6(\mathrm{C}-2$ '), 71.0 (C-5'), 71.4 (C-3'), 72.9 (C-4'), 89.5 (C-1'), 121.2, 121.3 (C-3, C-5), 140.1 (C-4), 149.0 (C-2, C-6), $167.3(\mathrm{C}=\mathrm{O})$; HREIMS $\mathrm{m} / \mathrm{z}$ calcd for $\mathrm{C}_{13} \mathrm{H}_{21} \mathrm{~N}_{3} \mathrm{NaO}_{5}[\mathrm{M}+\mathrm{Na}]^{+}$: 330.1060, found 330.1072.

\section{1-(1'-L-Arabinosyl)-2-isonicotinoyl-hydrazine $\mathbf{1 1 a}$ and $\mathbf{1 1 b}$}

Yield 36\%; IR (KBr) 3490, 3066, 2943, 1664, 1644, 1553, 1091 and $1044 \mathrm{~cm}^{-1}$; ${ }^{1} \mathrm{H}$ NMR (300 MHz, D O) $\delta 3.59-4.01$ (m, 5H, H-2', H-3', H-4', H-5', H-5'”), 4.08 (d, 1H, H-1' J 8.3Hz), 7.62-7.64 (m, $4 \mathrm{H}, \mathrm{H}-3, \mathrm{H}-5), 8.62-8.64$ (m, 4H, H-2, H-6); ${ }^{13} \mathrm{C}$ NMR $(300 \mathrm{MHz}$, D O) $\delta$ 61.4-77.9 (C-2', C-3', C-4', C-5'), 82.5-94.2 (C-1'), 122.0 (C-3, C-5), 140.7 (C-4), 149.7 (C-2, C-6), $155.1(\mathrm{C}=\mathrm{N}$, acyclic form), $167.5(\mathrm{C}=\mathrm{O})$.

\section{1-(1'-L-Ribosyl)-2-isonicotinoyl-hydrazine $\mathbf{1 2 a}$ and $\mathbf{1 2 b}$}

Yield 50\%; (oil); IR (CsI) 3376, 2926, 1669, 1551, 1065 and 1048 $\mathrm{cm}^{-1}$; ${ }^{1} \mathrm{H}$ NMR (300 MHz, D O) $\delta$ 3.59-4.18 (m, 10H, H-2', H-3',
H-4', H-5', H-5"), 4.42 (d, 1H, H-1'J 8.6Hz), 7.62-7.83 (m, 4H, $\mathrm{H}-3, \mathrm{H}-5), 8.64-8.68$ (m, 4H, H-2, H-6); ${ }^{13} \mathrm{C}$ NMR (300 MHz, $\mathrm{D}_{2} \mathrm{O}$ ) 反 60.8-72.8 (C-2', C-3', C-4', C-5', C-6'), 82.4, 93.8 (C-1'), 121.1 (C-3, C-5), 139.6 (C-4), 148.8 (C-2, C-6), 153.1 (C=N, acyclic form), $167.2(\mathrm{C}=\mathrm{O})$.

\section{1-(1'-L-Xylopyranosyl)-2-isonicotinoyl-hydrazine 13}

Yield 63\%; (oil); IR (CsI) 3388, 2924, 2855, 1667, 1553 and 1048 $\mathrm{cm}^{-1}$; ${ }^{1} \mathrm{H}$ NMR (300 MHz, D O) $\delta 3.09-3.23$ (m, 2H, H-2', H-5"), 3.32 (dd, 1H, H-3' J 8.9, J 8.7Hz), 3.46-3.49 (m, 1H, H-4'), 3.78 (dd, 1H, H-5' J 5.3, J 11.8Hz), 4.02 (d, 1H, H-1'J 8.8Hz), 7.51-7.53 (m, 2H, $\mathrm{H}-3, \mathrm{H}-5), 8.51-8.53$ (m, 2H, H-2, H-6); ${ }^{13} \mathrm{C} \mathrm{NMR}\left(300 \mathrm{MHz}, \mathrm{D}_{2} \mathrm{O}\right) \delta$ 66.7 (C-5'), 69.4 (C-4'), 70.9 (C-2'), 76.6 (C-3'), 90.8 (C-1'), 122.0 (C-3, C-5), 140.9 (C-4), 149.7 (C-2, C-6), $168.1(\mathrm{C}=\mathrm{O})$.

\section{ACKNOWLEGEMENTS}

We thanks CAPES and CNPq for fellowships.

\section{REFERENCES}

1. Munch, R.; Microb. Infect. 2003, 69, 74 .

2. Kaufmann, S. H. E.; Tuberculosis 2003, 83, 86.

3. De Souza, M. V. N.; Curr. Opn. Pulm. Med. 2006, 3, 167.

4. De Souza, M. V. N.; Vasconcelos, T. R. A.; De Almeida, M. V.; Cardoso, S. H.; Curr. Med. Chem. 2006, 13, 455.

5. Lourenço, M. C. S.; Vicente, F. R. C.; Henrique, M. G. M. O.; Candea, A. L. P.; Gonçalves, R. S. B.; Nogueira, T. C. M.; Ferreira, M. L.; De Souza, M. V. N.; Bioorg. Med. Chem. Lett. 2007, 17, 6895.

6. http://www.who, accessed in September 2008.

7. De Souza, M. V. N.; Vasconcelos, T. R. A.; Quim. Nova 2005, $28,678$.

8. Scior, T. S.; Garcés-Eisele, J.; Curr. Med. Chem. 2006, 13, 2205.

9. Janin, Y. L.; Bioorg. Med. Chem. 2007, 15, 2479.

10. Lourenço, M. C. S.; Ferreira, M. L.; De Souza, M. V. N.; Peralta, M. A.; Vasconcelos, T. R. A.; Henrique, M. G. M. O.; J. Eur. Med. Chem. 2008, $43,1344$.

11. Fu, L. M.; Shinnick, T. M.; Tuberculosis 2007, 87, 63.

12. Marrakchi, H.; Lanéelle, G.; Quémard, A.; Microbiology 2000, 146, 289.

13. Slayden. R. A.; Barry, C. E.; Microb. Infect. 2000, 2, 659.

14. Ventura, C.; Martins, F.; J. Med. Chem. 2008, 51, 612.

15. Fox, H. H.; J. Org. Chem. 1953, 18, 990.

16. Yale, H. L.; Losee, K.; Martins, J.; Holsing, M.; Perry, F. M.; Bernstein, J.; J. Am. Chem. Soc. 1953, 75, 1933.

17. Pasqualoto, K. F. M.; Ferreira, E. I.; Santos-Filho, O. A.; Hopfinger, A. J.; J. Med. Chem. 2004, 47, 3755.

18. De Souza, M. V. N.; Ferreira, M. L.; Pinheiro, A. C.; Saraiva, M. F.; De Almeida, M. V.; Valle, M. S.; TheScientificWorldJournal 2008, 8, 720.

19. De Oliveira, P. S. M.; Ferreira, V. F.; De Souza, M. V. N.; De Carvalho, E. M.; Quim. Nova 2008, 31, 776.

20. Bailey, K.; Butterfield, A.; Can. J. Chem. 1981, 59, 641.

21. Bendiak, B.; Carbohydr. Res. 1997, 304, 85.

22. IUPAC-IUBMB Carbohydrate Nomenclature; Carbohydr. Res. 1997, 297, 1.

23. Canetti, J.; Rist, E.; Grosset, R.; Pneumology 1963, 27, 217.

24. Franzblau, S. G.; Witzig, R. S.; McLaughlin, J. C.; Torres, P.; Madico, G.; Hernandez, A.; Degnan, M. T.; Cook, M. B.; Quenzer, V. K.; Ferguson, R. M.; Gilman, R. H.; J. Clin. Microbiol. 1998, 36, 362.

25. Vanitha, J. D.; Paramasivan, C. N.; Mycobacteriology 2004, 49, 179.

26. Reis, R. S.; Neves, I. Jr.; Lourenço, S. L. S.; Fonseca, L. S.; Lourenço, M. C. S.; Clin. Microbiol. 2004, 42, 2247

27. Shaffer, R.; Isbell, H. S.; J. Am. Chem. Soc. 1957, 79, 3864.

28. Iware, K.; Bull. Chem. Soc. Jpn. 1941, 16, 40. 